\title{
The relationship between on-budget and off-budget government *
}

\author{
David Joulfaian \\ U.S. Department of Treasury, Washington, DC 20220, USA \\ Michael L. Marlow \\ California Polytechnic State University, San Luis Obispo, CA 93407, USA
}

\begin{abstract}
This paper studies the hypothesis that controls on on-budget government spending leads to greater off-budget activity. Existence of a substitution effect suggests that our ability to control and measure the size of government is more difficult than previously thought.
\end{abstract}

\section{Introduction}

Modeling public sector growth is complex since government activities take many forms: on-budget spending, subsidies, tariffs, quotas, government-sponsored enterprises (GSEs), laws, regulations and guaranteed loans. This paper studies the hypothesis that direct and indirect controls (e.g., tax-an-expenditure limitations, election periods, taxpayer revolt/complaints related to existing tax burdens) on government activities lead to substitution from controlled activities to those activities not subject to those controls. We examine the causal relation between the on-budget spending and off-budget (GSEs) activities of state and local (S\&L) governments.

\section{Evasion of controls}

Lack of useful data is the primary reason why little research has been conducted on the evasion of controls by governments. Because of their visibility, most controls are placed on on-budget spending. For example, balanced budget rules are commonly placed on deficit numbers that are determined by the difference between on-budget revenues and expenditures. However, many off-budget activities exist and, to some extent, are substitutable with one another. For example, subsidies to domestic firms and import restrictions on foreign competitors are substitutable activities. Another example is a law requiring all employers to provide minimum levels of health insurance as a substitute for on-budget government provision. Congressional Budget Office, $\mathrm{CBO}$, (1983) and Bennett and

\footnotetext{
* The views expressed here are those of the authors and should not be attributed to the U.S. Department of Treasury.
} 
DiLorenzo (1982) provide examples of political circumvention of controls on on-budget activities. Circumvention often takes the form of off-budget public enterprises, or GSEs. Bennett and DiLorenzo argue that because the finances of GSEs are not usually approved by voters, GSEs offer an excellent outlet for the 'constrained' politician. Marlow and Joulfaian (1989) find that governments with large on-budget sectors also have relatively large off-budget sectors as well.

A recent example of a GSE is FICO (The Financing Corporation) which, in 1987, was granted authority to issue $\$ 10.8$ billion in debt to be used by FSLIC to liquidate, or merge with healthier firms, insolvent savings and loans. Even though FICO was created by government, is operated by government appointees and serves solely to finance a government activity (deposit insurance), its activities do not show up on the government's books and its debt exerts no net effect on on-budget spending. ${ }^{1}$

Events in fiscally-distressed Massachusetts provide another example. During 1989, the Governor and state legislatures were under pressure to reduce the state's widening budget deficit without incurring cuts in services or raising taxes. To this end, the state government stopped paying for snow removal expenditures on the Massachusetts Turnpike but required the Authority, a GSE, to continue such services. The latter is empowered to set whatever toll rates its deems necessary to cover its expenditures. Consequently, the Authority raised its rates by at least $30 \%$ as an administrative decision which does not require the approval of the legislature. While service level was unchanged, the state's books showed a reduction in spending and the deficit. Of course, taxpayers continue to pay for the service.

\section{Empirical evidence}

Granger-causality tests are conducted using annual data on the on-budget and off-budget (GSE) activities of $S \& L$ governments over the only currently-available time period, 1963-1986. ${ }^{2}$ On-budget data are the expenditures of S\&L governments (net of federal grants) as reported in Tax Foundation (1988). Off-budget data are defined as the gross state product (GSP) of GSEs as reported in the U.S. Department of Commerce (1988) and is sum of the earnings, subsidies, and the surpluses or deficits of such establishments. These GSEs encompass power, electric, gas, water, sewage, transportation, highways and lotteries. Evidence in support of our hypothesis would be indicated by off-budget causing on-budget activity. Bi-directional causality would suggest that the two activities determine each other while lack of causality suggests that no relations exist.

Two definitions of activities are considered: Nominal and as percentages of GSP. The latter specification suggests the direction of the relative importance of government activities as a share of the economy and partially solves the problem of finding a mutually appropriate deflator for on-budget spending and the output of the GSEs. To determine if the data are stationary, we regressed the data on a simple time trend. ${ }^{3}$ Appropriate transformations appear to be log first-difference for on-budget spending and $\log$ second-difference for GSE output. We have chosen symmetric lag lengths, ranging from one-to-five years. ${ }^{4}$

1 CBO (1989) predicts that issuance of $\$ 10.8$ in FICO debt, rather than Treasury debt, costs an additional $\$ 3$ billion over 30 years in interest payments. Another recently-created GSE to resolve the savings and loan 'crisis' is REFCORP which CBO (1990) predicts will take off-budget about \$30B in government spending in 1990 and 1991.

2 We used a more detailed listing of this data provided by the U.S. Department of Commerce than is currently published.

3 See Caines et al. (1981) and McMillan and Fackler (1984) for a discussion of this technique.

4 See Guilkey and Salemi (1982) and Thornton and Batten (1985) for the relevant issues. Note that our limited degrees of freedom also limit the power of lag-length selection tests. 
Table 1

Granger causality tests of on- and off-budget activities. ${ }^{e}$

\begin{tabular}{|c|c|c|c|c|}
\hline \multirow{2}{*}{$\begin{array}{l}\text { Hypothesis: } \\
\text { Lag }\end{array}$} & \multicolumn{2}{|c|}{ Off causes on } & \multicolumn{2}{|c|}{ On causes off } \\
\hline & $F$-statistic & Lagged coeff. $^{d}$ & $F$-statistic & Lagged coeff. $^{d}$ \\
\hline \multicolumn{5}{|c|}{ Nominal Specification } \\
\hline \multirow[t]{2}{*}{$(1,1)$} & 0.97 & 0.57 & $3.32^{\mathrm{a}}$ & $-0.13^{b}$ \\
\hline & & 0.98 & & 1.82 \\
\hline \multirow[t]{2}{*}{$(2,2)$} & 0.32 & 0.78 & $6.48^{\mathrm{c}}$ & $-0.25^{c}$ \\
\hline & & 0.73 & & 3.34 \\
\hline \multirow[t]{2}{*}{$(3,3)$} & 0.26 & 1.59 & $8.82^{c}$ & $-0.45^{c}$ \\
\hline & & 0.76 & & 3.51 \\
\hline \multirow[t]{2}{*}{$(4,4)$} & 1.01 & 5.59 & $7.32^{\mathrm{c}}$ & $-0.61^{c}$ \\
\hline & & 1.91 & & 2.93 \\
\hline \multirow[t]{2}{*}{$(5,5)$} & 1.11 & 9.77 & $5.58^{\mathrm{c}}$ & $-0.83^{\mathrm{c}}$ \\
\hline & & 1.64 & & 2.77 \\
\hline \multicolumn{5}{|c|}{ Percent of GSP Specification } \\
\hline \multirow[t]{2}{*}{$(1,1)$} & 2.80 & 0.54 & $5.88^{b}$ & $-0.34^{b}$ \\
\hline & & 1.67 & & 2.42 \\
\hline \multirow[t]{2}{*}{$(2,2)$} & 0.13 & 0.19 & $4.18^{b}$ & $-0.45^{b}$ \\
\hline & & 0.22 & & 2.38 \\
\hline \multirow[t]{2}{*}{$(3,3)$} & 0.19 & 1.15 & $2.64^{\mathrm{a}}$ & $-0.60^{b}$ \\
\hline & & 0.59 & & 1.99 \\
\hline \multirow[t]{2}{*}{$(4,4)$} & 0.16 & 1.29 & 2.53 & $-1.06^{c}$ \\
\hline & & 0.47 & & 2.67 \\
\hline \multirow[t]{2}{*}{$(5,5)$} & 3.76 & -0.70 & $11.37^{c}$ & $-1.84^{c}$ \\
\hline & & 0.32 & & 6.20 \\
\hline
\end{tabular}

d $t$-statistic below estimated sum of lagged 'causal' coefficients. ${ }^{a},{ }^{b}$ and ${ }^{c}$ refer to 10,5 and $1 \%$ levels of significance.

e For the percentage of GSP specification, both on-budget and off-budget data are divided by gross state product. Data on on-budget activities was transformed into $\log$ first-difference and the data on off-budget activity transformed into the change in the log first-difference.

Table 1 displays the Granger-causality tests. The partial $F$-statistic tests the null hypothesis that all coefficients on the lagged causal independent values are zero. The $t$-statistics on the sum of the coefficients of past values of 'causal' variables test if they, as a sum, exert any permanent influences on the dependent variable. If not, then any influences are transitory in nature. Test statistics indicate that on-budget activities lead and hence 'cause' off-budget activities. Overall, causal influences are found to be permanent and to carry a negative sign which suggests that past increases in on-budget activities cause decreases in current off-budget activities. With the exception of the $(4,4)$ lag structure in the percent of GSP specification, all $F$ - and $t$-statistics reject the hypothesis of no relation.

\section{Conclusion}

Evidence of a permanent causal influence running from on-budget activity to off-budget activity indicates support for the hypothesis that a degree of substitution exists between these two activities. The negative direction may indicate that past growth in on-budget activities have led to greater constraints on that activity and therefore to greater substitution into off-budget activities. The 
evidence should not be interpreted as indicating that past increasing levels of on-budget activity lead to decreasing levels of off-budget activity. Rather, the results indicate that past positive growth in on-budget activity has led to lower changes in growth in off-budget activity. The essential difference is that the latter interpretation does not necessarily suggest that this substitution must cause total government size to either rise or fall; only that there exists some degree of substitutability between on-budget and off-budget growth. This substitution suggests that measurement of government requires listing of its many diverse activities. A growing off-budget sector suggests the difficulty in attempting to control government when controls are only placed on on-budget activities.

\section{References}

Bennett, James T. and Thomas J. DiLorenzo, 1982, Off-budget activities of local governments: The bane of the Tax Revolt, Public Choice 39, 333-342.

Caines, P.E., C.W. Keng and S.P. Sethi, 1981, Causality analysis and multivariate autoregressive modeling with an application to supermarket sales analysis, Journal of Economic Dynamics and Control 267-298.

Congressional Budget Office, 1983, Balancing the federal budget and limiting federal spending: Constitutional and legislative approaches (Congressional Budget Office, Washington, DC).

Congressional Budget Office, 1989. The savings and loan problem: A discussion of the issues, Staff Memorandum Prepared for the Committee on Ways and Means, Feb. 1989.

Congressional Budget Office, 1990, The economic and budget outlook: Fiscal years 1991-1995. A Report to the Senate and house Committees on the budget, Part 1 (Congressional Budget Office, Washington, DC) Jan. 1990.

Guilkey, D.K. and M.K. Salemi, 1982, Small sample properties of three tests for Granger-causal ordering a bivariate stochastic series, Review of Economics and Statistics 64, 668-680.

Marlow, Michael L. and David Joulfaian, 1989, The determinants of off-budget activity of state and local governments, Public Choice 63, 113-123.

McMillan, W. Douglas and James S. Fackler, 1984, Monetary vs. credit aggregates: An evaluation of monetary policy targets, Southern Economic Journal, 711-723.

Tax Foundation Inc, Facts and Figures on Government Finance, various issues.

Thornton, Daniel L. and Dallas S. Batten, 1985, Lag-length selection and tests of Granger causality between money and income, Journal of Money, Credit and Banking, 164-178.

U.S. Department of Commerce, 1988, Gross state product by industry, 1963-1986, Survey of Current Business 68, 30-46. 